\title{
A Post-Mortem of Regional Innovation Policy Failure: Scotland's Intermediate Technology Initiative
}

Ross Brown, School of Management, University of St Andrews, The Gateway, North Haugh, St Andrews, Fife, KY16 8XE, UK. Email: Ross.Brown@st-andrews.ac.uk

Geoff Gregson, JR Shaw School of Business, Northern Alberta Institute of Technology (NAIT), 11762 - 106 Street NW, Edmonton, AB T5G 2R1, Canada. Email: geoffg@nait.ca

Colin Mason, Adam Smith Business School, University of Glasgow, University Avenue, Glasgow, G12 8QQ, UK. Email: Colin.Mason@glasgow.ac.uk

\begin{abstract}
The Intermediate Technology Initiative (ITI) was one of the most ambitious 'systemic' regional innovation policy instruments developed in the UK in recent years. However, little of the ITI's anticipated outputs materialised and the programme was prematurely terminated. This paper examines the reasons for its failure which largely centred on the programme's inappropriate design. The findings suggest that greater recognition needs to be given to the specificities of local entrepreneurial ecosystems when designing, aligning and executing systemic innovation policy instruments. It is argued that paying greater attention to policy failures could potentially help innovation scholars better understand how innovation systems function.
\end{abstract}




\section{KEY WORDS}

Regional innovation system Commercialisation Entrepreneurial ecosystem Public policy

Peripheral Region

\section{JEL CODES}

M 13, 012, 031, 032, 033038 


\section{INTRODUCTION}

Since the 1990s the focus of industrial and technology policies has shifted from science and technological development in favour of interventions that help build innovation systems, foster networks, develop institutions and align strategic priorities (OECD, 2010; COX and RIGBY, 2013; WARWICK, 2013). A key manifestation of this trend is the increasing significance attached towards 'systems of innovation' (LUNDVALL, 1992, 2007; FREEMAN, 1995; EDQUIST, 2004; SHARIF, 2006; DODGSON et al, 2011). Adopting this approach helps identify 'systemic problems' (EDQUIST, 2011) within innovation systems which 'systemic policy instruments' are designed to tackle (SMITS and KUHLMANN, 2004; WIECZOREK and HEKKERT, 2012). These policy instruments are 'integrated coherent sets of tools designed for a specific innovation system (or part of a system)' (WIECZOREK and HEKKERT 2012, p. 86). The formulation of policies and programmes that attempt to enhance technology transfer and increase the commercialisation of university research are frequently the focus of these instruments (EDQUIST 2004; HEWITT-DUNDAS and ROPER, 2011).

In recent years, these policy trends have been evident in the United Kingdom, especially in the devolved regions of Northern Ireland, Scotland and Wales (KEATING, 2005; LYALL, 2005; 2007). In the case of Scotland, one of the most ambitious signs of this kind of policy experimentation was the establishment by Scottish Enterprise of the Intermediate Technology Initiative (ITI) (HUGGINS and KITAGAWA, 2012) as part of the Scottish Government's economic strategy 'Smart, Successful Scotland' (SCOTTISH EXECUTIVE, 2004). Established in 2003, it was intended to have a major transformational impact on the Scottish economy by tackling its low levels of 
university research commercialisation, limited high-tech new venture formation and below UK average levels of business R\&D expenditure. The key focus of the programme was on promoting the formation of new technology based firms (NTBFs).

Its projected budget of $£ 450 \mathrm{~m}$ was a clear indication of the political importance attached to the programme. The Scottish First Minister at the time, Jack McConnell, claimed that the ITI would 'have a crucial role in making the giant leap to more world beating companies and high-quality jobs'. Given this high level of expenditure and high expectations, the policy became highly visible within the Scottish policy landscape and was closely monitored by politicians, the Scottish media and international agencies (OECD, 2004). The ITI was meant to be a genuine attempt to affect change at the level of the Scottish innovation system as a whole (COOKE, 2004; ROPER et al, 2006; EDGAR, 2009) and was closely aligned with existing science and technology policies in Scotland which were heavily focused on the strengths of Scotland's universities (LYALL, 2005).

Despite these high expectations and political 'buy-in', the ITI failed to achieve its objectives and was prematurely terminated (The HERALD, 2010). To date, there has been no systematic and objective examination of this strategically important policy intervention. This paper seeks to rectify this by asking the simple but multi-dimensional question: 'what did the ITI achieve in terms of its objectives and why did these fall so far below expectations?' Policy failures are rarely acknowledged and even less likely to be the subject of analysis, preventing the opportunity for learning. MARKUSEN (2000) notes that despite the fact that technology policy failures are 'numerous and costly,' remarkably little research examines such failures. She 
claims it is often implicitly deemed to be less promising than examining successful initiatives. Yet, without insights into the causal factors underlying policy failure: 'how can we fashion an effective program of government intervention?' (MARKUSEN, 2000, p. 136). By examining a high profile case of systemic innovation 'policy failure', this paper aims to address this significant omission within the literature.

\section{LITERATURE REVIEW: THE THEORY AND PRACTICE OF SYSTEMIC INNOVATION POLICY}

The Theory of Innovation Systems

One of the most important theoretical perspectives within the field of innovation policy over the past twenty years has been the concept of the national innovation systems (NIS) (LUNDVALL, 1992; FREEMAN, 1995; COOKE et al, 1997; SHARIF, 2006). This perspective strongly embraces an evolutionary theory of economic change (NELSON and WINTER, 1982; METCALFE, 1997). Within this neo-Schumpeterian perspective, innovation is viewed as a non-linear, relationally 'embedded' and geographical bounded phenomena (LUNDVALL, 1992; MORGAN, 1997; GERTLER, 2010) where capitalism is driven 'by the pressures of creative destruction' (BEST, 1990, p.119). Under these conditions, it is widely accepted that government policies often play a central coordinating role within the innovation process (BEST, 1990; FREEMAN, 1995; DODGSON et al, 2011; COX and RIGBY, 2013). A key focus of the NIS concept is the strong emphasis it places on the relational aspects between different institutional actors and how this facilitates the innovation process in a 'crowded space' where firms and institutions all closely intermingle (ACS and VARGA, 2005, p. 323). 
Much of the initial innovation systems literature is national or sectorally focused (CARLSSON et al, 2002; MALERBA, 2002) and so ignores the importance of regional factors in shaping both the local entrepreneurial system and the policy context. This omission is important because policy frameworks within the sphere of innovation policy are often regionally constructed. However, since the late 1990s, scholars have begun examining the relevance of these systemic concepts for regions and sub-national actors (COOKE et al, 1997; ASHEIM et al, 2011). According to some, a regional innovation system (RIS) is not just a smaller scale or 'proto' NIS (HOWELLS, 1999) because knowledge transfer, agglomeration economies and external economies operate differently at the level of a region (OUGHTON et al, 2002). At its most rudimentary level, a 'regional innovation system can be thought of as the institutional infrastructure supporting innovation within the production structure of a region' (ASHEIM and COENEN, 2005, p. 1177). Universities, public sector research organisations, skills development bodies, regulatory bodies and - increasingly - venture capitalists are key actors within a RIS (COOKE et al, 1997).

A RIS has two main sub-systems: a 'knowledge generation' sub-system and a 'knowledge exploitation' sub-system (COOKE, 2004). Despite this, policy makers often promote and focus heavily upon 'knowledge generation' policies. This is because of the strong belief that the public returns to innovation outweigh the private returns which are often spatially localised (AUDRETSCH and FELDMAN, 1996). Therefore, to promote innovation within regions, policy makers often look to create knowledge or infrastructure capacity-building at a regional level (COOKE, 2000). Recent empirical research in Quebec's coastal region shows that regional policy makers frequently generate new institutions but fail to recognise the importance of the demand for knowledge within their policy frameworks (MELANCON and DOLOREUX, 2013). 
According to MELACON and DOLOREUX, 'the creation of new organizations does not appear to be sufficient to guarantee that these organizations will be strongly engaged with other actors in the region' (2013, p. 1570). New institutional arrangements are therefore no 'panacea' for the lack of dynamism within firms situated within a RIS (MELANCON and DOLOREUX, 2013, p. 1569).

Getting the Right 'Policy Mix'

The recent literature on innovation policy now increasingly focuses on the importance of designing the correct 'policy mix' (FLANAGAN et al, 2011) or 'instrument mix' (BORRAS and EDQUIST, 2013). This is defined as the 'specific combination of innovation-related policy instruments which interact explicitly or implicitly in influencing innovation intensities' (BORRAS and EDQUIST, 2013, p. 1520). Such a focus highlights the importance of interactions and interdependencies which coalesce to influence the effectiveness of public policies and to highlight the 'trade-offs' and 'tensions' embedded within any policy mix (FLANAGAN et al, 2011). According to some, the problematic nature of the design of the 'instrument mix' is what makes innovation policy instruments 'systemic' (BORRAS and EDQUIST, 2013, p. 1513). This is because many innovation policies are constructed and mediated through a complex array of multi-actor, multi-scalar and multi-stakeholder relationships. Consequently, policy making within this environment is often highly politicized and contested (UYARRA, 2010), with many innovation instruments selected by a rather random or 'ad hoc' set of decisions and criteria (BORRAS and EDQUIST, 2013). 
Yet, the complex interplay of institutional and political actors and how this shapes innovation policy has often been overlooked by innovation policy scholars. This has created certain shortcomings not only within the innovation literature but also within innovation policy itself. Given that 'innovation policy is what its instruments are' (BORRAS and EDQUIST, 2013, p. 1521), the innovation policy literature needs to go much deeper to assess the causal mechanisms shaping the institutional and operational effectiveness underpinning these policies. This is particularly important because of the highly risk-oriented nature of technology and policy which can fail just as easily as the innovation strategies deployed by individual firms (METCALFE, 1997; MAZZUCATO, 2013).

The effectiveness of policy instruments 'plays a crucial role as a way to open up new growth paths' (CRESPI and QUATARO, 2013, p. 1447). Therefore, achieving the optimum innovation policy mix is the key to unlocking the puzzle of effective policy implementation. If innovation policy is to become more adaptive to the needs of key innovation actors, greater recognition needs to be given to the specificities of how policy operate and importantly, what undermines the effectiveness of various 'policy combinations'. For this to happen, a key antidote is a deep evolutionary examination of the specificities and intricacies which shape the dynamics of the overall 'policy mix'.

\section{Assessing Policy Effectiveness}

Another key criticism which can be levelled at the innovation policy literature is a lack of detailed analysis of how public policies operate within innovation systems on a longer-term 
evolutionary basis (UYARRA, 2010; UYARRA and FLANAGAN, 2010). Research tends to focus on 'what policy makers ought to do' while being less concerned with 'what policy makers actually do' (UYARRA, 2010, p. 130). Most importantly, it portrays the process of innovation policy making as a simple rational exercise which is constructed by optimal decision making and perfect information. Just as there are a host of variegated actors within a RIS, most actors have quite distinct ideas and self-interests which in turn govern much of their behaviour. Some scholars rightly claim that much greater empirical attention needs to focus on 'actual' as opposed to 'idealised' processes of policy learning and to better understand the roles that experts, analysts and evaluators play in those processes vis-a-via other actors' (FLANAGAN et al, 2011, p. 711).

The relevance of the current literature may also be circumscribed by the fact that most empirical studies examining the effectiveness of innovation policies tend to be cross-sectional; providing a snapshot at one point in time (see, for example, ROPER et al, 2006), rather than demonstrating how the RIS evolves and upgrades over time (BERGEK et al, 2008). These studies can be misleading (SALTER and MARTIN, 2001) because public policies often adapt according to market demands and incorporate changes suggested by stakeholders and recipients such as individuals and firms. Therefore, it is important to view the 'policy mix' within a RIS as a dynamic rather than a static phenomenon.

Standard forms of evaluative assessments of innovation policy instruments have also been strongly criticized for being too narrowly focused on performance measures (AUTIO, 1998; DIEZ, 2001; MOLINA and GREGSON, 2002). Although more nuanced qualitative-oriented 
evaluations are now being undertaken (YOUNG et al, 2008), traditional approaches towards evaluating innovation policies strongly favour quantitative methods (FELDMAN and KELLEY, 2006); treating the process by which innovative inputs lead to outputs as something of a 'black box' (GREENE and STOREY, 2007; FLANAGAN et al, 2011). Such approaches arguably hinder a proper understanding of the complex causal processes at work and tell us little about why interventions succeed or fail (TUROK, 1991). Indeed, evaluation approaches which have tended to rely on quantitative performance indicators tend to ignore the wider systemic factors affecting the success of policy interventions (ARNOLD, 2004).

Unravelling the complex interplay between the different combinative factors which mediate and shape the success of 'policy mixes' is methodologically difficult. In the context of this study, we believe that there is invaluable learning to be gained from assessing the causes and consequences (both intended and unintended) of systemic policy interventions. With its wideranging objectives of unlocking important 'blockages' in the Scottish RIS (COOKE, 2004, p. 94), the ITI provides an excellent case study of this new kind of systemic policy instrument. In line with others, we believe that much greater attention needs to be paid to the complex interrelated 'histories' of different 'policy mixes' (FLANAGAN et al, 2011), especially in relation to policy failures (MARKUSEN, 2000). Therefore, the main aim of this paper is to provide learning which can inform our understanding of how policy instruments interact (and indeed collide) with their economic and institutional environment.

\section{METHODOLOGY AND DATA SOURCES}


A longitudinal case study methodology was utilized to examine the ITI case during its seven year (of a projected ten-year programme) lifespan (2003-2010). The study sought to tease out the impact of the policy intervention on a variety of levels. In order to maintain 'construct validity' (EASTERBY-SMITH et al, 2002), the research used multiple sources of evidence built up over a period of time. The wide-ranging nature of the research process helped to mitigate the pitfalls of mainstream evaluative research which can be influenced and distorted by the project sponsors (BOZEMAN, 2000). Overall, this detailed qualitative research approach enabled us to unpack the 'multifaceted, temporally unfolding situations and causal mechanisms' (GRAEBNER et al 2012, p. 279).

The research drew upon a wide range of primary and secondary data sources. First, a wide range of unpublished background material was examined; notably internal reports by the ITI and Scottish Enterprise. This included analysis of the original approval papers which outlined the rationale for the ITI, feasibility studies and forecasted benefits. Numerous newspaper articles, company reports and websites have also been examined as part of the background analysis for the research. Since the termination of the programme, obtaining evidence on the ITI's performance has been a challenge on account of its politically sensitive nature. Some of the evidence on the final impact of the programme is therefore drawn from information derived from a Freedom of Information request submitted by a Scottish newspaper (The HERALD, 2013).

Second, the research included in-depth interviews with key stakeholders involved in the Scottish innovation system. These interviews were conducted at three points in time. Prior to 
the launch of the programme, fifteen interviews were conducted in 2003 with senior figures representing three categories of actors central to the Scottish RIS; universities, government and the private sector, including university technology transfer managers $(n=9)$, Scottish Executive and Scottish Enterprise senior managers $(n=2)$ and with public-private sector agencies $(n=4)$ supporting technology commercialisation. Mid-way through the programme, in 2007, 19 interviews were undertaken with various actors' involved in the programme. These included contractors who received research contracts, recipients of licenses from the commissioned research programmes and staff within the ITI and Scottish Enterprise. It also included interviews with 10 companies which were working with the ITI to undertake R\&D programmes with a view to licensing the IP produced. Following the termination of the programme in 2010, a final round of ten interviews was conducted with universities, technology entrepreneurs, policy makers and SMEs across Scotland. In summary, a total of 44 interviews have been undertaken over the ten years in which the research has been conducted.

Where possible, the interviews were taped and transcribed. However, a significant number of people declined to have their views recorded. The interview material was interpreted using a partial 'grounded' approach in which the data were systematically analysed to tease out themes, patterns and categories. When key categories emerged they were refined and reevaluated. During the final phase of the interviews, some of these themes were then fed back to participants to assess the veracity of the earlier findings as others have done with policy oriented research (FISCHER and REUBER, 2003).

\section{THE INTERMEDIATE TECHNOLOGY INITIATIVE: AN OVERVIEW}


The ITI was launched in 2003 with the objective of identifying emerging global market opportunities in the three key sectors of Life Sciences, Techmedia (i.e. ICT and digital media) and Energy It was designed to undertake four core functions: foresighting, programme development, programme management and value release/commercialisation (Figure 1). The model was heavily predicated on the ability of the programme to undertake advanced technological foresighting.

[Insert Figure 1 about here]

Thematic research areas were then developed into formal research programmes and evaluated on four core criteria:

- Forecasting new global market opportunities;

- Creation of novel and protectable intellectual property;

- Creation of new businesses with identifiable routes to market;

- Complementing the Scottish corporate and research base and Scotland's ability to exploit the technology.

Following this assessment, research programmes were then devised. Each R\&D programme was managed by a programme manager whose role was to ensure that the knowledge and know-how from the programme was effectively identified, captured and (most importantly) protected. Typically, the range of technical development on any programme required multiple R\&D providers from across the academic and business spectrum. The average size of expenditure per programme was $£ 5.8 \mathrm{~m}$, a figure much higher than originally anticipated by 
Scottish Enterprise. This was primarily because in some cases, programmes had to commission further R\&D to bring them 'closer to market.'

Intellectual Property rights (IPRs) were fundamental to the ITI's operating model. Ownership of the IP by ITI Scotland was considered essential by Scottish Enterprise and programme directors to allow the platform potential of the technologies to be exploited in ways that created direct benefits to the Scottish economy. IP ownership was also needed to comply with stringent European Union (EU) State Aid rules. Hence, in all of the R\&D programmes undertaken, the ITI sought to own the pre-competitive IP generated which it sought to license to commercial partners at market rates. It was anticipated that the main beneficiaries would be Scottish firms who license the technology but, failing that, firms outside Scotland were also eligible to license the IP.

The final and perhaps critical stage of the ITI model was the commercial exploitation of the intellectual assets developed. The economic impacts were expected to be derived in two main of ways. First, the key commercialisation route was expected to be through the creation of NTBFs which were thought likely to emerge from research providers and commercialisation partners. University spin-offs were initially expected to be the most important source of NTBFs. Second, the other expected strand of commercialisation was via existing businesses licensing IP to enable new product or service development. Commercialisation partners were expected to produce a plan showing their proposals for exploiting the technology. Licenses for IP were negotiated on the content of detailed business plans submitted to the ITIs by commercial partners. 
Assistance with the commercialisation process was provided by the public sector in terms of business support for the NTBFs anticipated to emanate from the research programmes. The responsibility for this business support rested with Scottish Enterprise through existing support mechanisms such as the High Growth Start-Up Unit within Scottish Enterprise. In this respect, the model resembled the 'assisted linear' approach to innovation (ETZKOWITZ, 2006). The ambitious nature of ITI was reflected in the specific performance metrics adopted. Scottish Enterprise predicted that within the ITI's first ten years, at least 75 NTBFs would be operating as a direct result of the programme. This figure was anticipated to rise to around 170 after 20 years.

\section{THE PERFORMANCE OF THE ITI}

By March 2013, the final budgetary outlay of the programme stood at $£ 231 \mathrm{~m}$; a figure which was just over half of the original anticipated ten year budget for the programme ( $f 450 \mathrm{~m})$. To put this into context, in 2012, the total figure for business expenditure on research and Development (BERD) in Scotland was $f 707 \mathrm{~m}$ or $4.1 \%$ of the overall level of UK BERD (SCOTTISH GOVERNMENT, 2013). The ITI programme therefore constituted a sizeable sum equivalent to about one-third of annual Scottish BERD.

By March 2013, when the programme was effectively terminated, the programme had achieved the following outcomes:

- 22 R\&D programmes completed;

- 94 patents registered;

- 5 NTBFs currently trading; and 
- 24 licensing deals, with $f 600 \mathrm{k}$ in licensing revenue having been paid to the ITI.

The $22 R \& D$ programmes that have been completed across the three main sectoral divisions of the ITI (ranging in size from $f 30 \mathrm{~m}$ in the case of the Cardiac Biomarkers programme to just £1.8m by the Games-based e-Learning R\&D programme) resulted in 94 patents being registered; an average of around 13 per annum. To put this figure into perspective, there were 207 patents granted to Scottish firms in 2011 (INTELLECTUAL PROPERTY OFFICE, 2012). One of the most innovative technology-based firms in Scotland, Wolfson Microelectronics, a supplier of semiconductor devices to Apple and Samsung, registered over 60 patents in 2011 alone (INTELLECTUAL PROPERTY OFFICE, 2012). When seen in this context, the number of patents generated over a seven year operating lifespan does not seem to constitute an exceptional output for the volume of expenditure committed.

However, the key failure of the ITI was not in terms of the research output it produced but rather the lack of commercial outputs generated. In this respect, the two key 'output' indicators of the programme were the small numbers of NTBFs created and licenses awarded. In terms of the former, just five NTBFs have resulted from the programme. By any yardstick, this figure seems low, but especially since the original aim was to generate 75 NTBFs on completion of the programme [1]. The second indicator, which further underlines the weak performance of the programme, is the very low level of licensing revenue generated by the programme. The ITI concluded 24 licensing deals producing revenue of $£ 600 k$, which implies that the vast majority of patents have not been commercially exploited. It is this low level of licensing revenues which has been the source of much of the criticism directed towards the 
programme (THE HERALD, 2013). There is no publicly available information on either the location of the licensees so we cannot assess 'where' the IP produced is being commercially exploited, or how many FTE jobs were created within the ITI's R\&D research providers.

Following the internal review of the programme in 2008, a number of modifications were made. First, it was decided that the programme should be brought in-house within Scottish Enterprise (EDGAR, 2009). This decision, which took effect in 2009, was taken to ensure that greater efforts were directed towards the commercialisation of the R\&D programmes. In 2010, with the programme's overall budget standing at $f 216 \mathrm{~m}$, it was decided that no new R\&D programmes would be commissioned. There was a further expenditure of $£ 15 \mathrm{~m}$ on the remaining R\&D programmes but since March 2013, there has been no further expenditure committed to the ITI.

\section{EXPLAINING POLICY FAILURE}

Our analysis identifies two main sets of factors which limited the effectiveness of the ITI. The first set comprises various internal institutional issues. These include the nature of the research programmes, the stance towards IPRs, the ITI commercialisation procedures and internal ITI governance issues. The second set revolved around the systemic characteristics underpinning the Scottish entrepreneurial ecosystem. These two sets of factors coalesced to critically weaken the overall effectiveness of the programme. These are summarised in Table 1.

[Insert Table 1 about here] 


\subsection{Institutional Factors and Policy Underperformance}

\subsubsection{The Nature of the Research Programmes}

A key institutional factor impeding the successful operation of the ITI was the pre-competitive or 'blue-sky' nature of the research programmes. The R\&D programmes were heavily oriented to producing novel IP which by its very nature was far from market. This had two negative consequences. First, while many companies viewed the foresighting work to be of interest, the majority felt that the technology being developed was just too far advanced for their own requirements. The potential pitfalls of this approach were identified by one of the stakeholders prior to the launch of the programme:

'if SMES do not have the required technology/knowledge to exploit the market opportunity, then the pre-competitive research commissioned by the ITI may not find its way back to the Scottish economy and remain in the research environment'

Second, because of the formative nature of the technology, the programme did not generate applications that were immediately commercialisable. In most cases, the programmes produced 'platform' technologies which many of the potential users considered not to be 'market-ready'. Most of the programmes therefore required further work to be done to take the IP created to a stage which could be properly commercially applied. This was also a 
potential problem that some stakeholders had anticipated prior to the programme's launch. One remarked:

'if the fore-sighting of the ITI involves global players, then the technologies commissioned will be even more advanced and harder to absorb by local SMEs, and most of this technology will be absorbed by multinationals'

\subsubsection{Intellectual Property Rights}

The second key institutional issue was the approach adopted by the ITI's regarding IPRs. The ITI's stance on IP ownership - that all background and foreground IP developed through the research programmes was owned by the ITI - conflicted with the rigid stance of Scottish universities towards IP ownership; which emphasises the need to protect the IP they produce in order to maximise the benefits of research in terms of future income generation from license agreements and equity stakes in spin-off companies. As a consequence, some universities refused to engage in the ITI research programmes. When involvement between the universities and ITIs occurred, negotiations and transactions often became very protracted, and in some cases, hostile, making them difficult to conclude This rigid stance of universities has acted as a 'critical inhibitor', preventing many of the universities in Scotland participating in the ITI research programmes. However, it needs to be acknowledged that a more favourable outcome from a closer involvement of universities is questionable, in view of their poor track record in 
producing spin-offs of any scale (TARGETING TECHNOLOGY, 2008; HARRISON and LEITCH, 2010). This issue of IP ownership was identified as a key concern by university technology transfer directors prior to the launch of the ITI.

The attitude of the ITI towards IPR also impinged on both commercial research providers and also the potential recipients of licenses. The ambiguous and contested nature of IPR issues became apparent during the interviews with research providers (who were also potential licensees). Some companies - especially those which were venture capital (VC) backed - did not wish to license the technology from the ITls because they did not feel that this would have provided them with sufficiently protected IP. One renewable energy firm stated that in order to even consider licensing IP, they would 'need exclusive IP' to allay any fears to their VC backers. Indeed, studies have shown that VC-backing is strongly linked to IPR protection (MANN and SAGER, 2007). Even the offer from the ITI of 'exclusive' licenses was not sufficient for some early stage companies which wanted the security of outright ownership of their IP. In summary, the decision on behalf of the ITIs to insist on outright ownership of the IP inadvertently prevented most Scottish universities and existing businesses from engaging in the programme, making the ITI-mediated RIS a rather 'closed' rather than 'open' innovation system.

\subsubsection{Research Commercialisation Procedures}

The ITI's approach towards commercialisation of the research, particularly its licensing procedures, was also problematic. There was a requirement to pay up-front fees - often as 
much as $£ 150,000$ - to obtain an exclusive license. This fee was often in addition to the payment of ongoing royalty fees to the ITI on sales from any new products developed as a consequence of the IP being exploited. Indeed, in nearly half of the licenses examined during this research, an up-front license fee was demanded, in addition to on-going royalty payments.

The ITI was also criticised for being inflexible in the negotiation of license agreements. One potential SME licensee interviewed enquired about the possibility of obtaining a 'demonstrator' license so the firm could show the potential applications to a potential customer. This was strenuously opposed by the ITIs, so the company refused to license the IP. This lack of flexibility clearly inhibited the commercialisation of the technology, especially by smaller companies with limited finances for such high risk research expenditure. A number of firms felt that there was too much emphasis on producing IP and not enough emphasis on the need to 'create jobs'. Mid-way through the lifespan of the programme in 2007, one research provider presciently remarked: 'The ITI may end up just creating more IP in Scotland'.

\subsection{Systemic Factors Mediating Policy Underperformance}

The second set of factors focus upon the specific nature of the knowledge exploitation subsystem in the Scottish RIS. The nature of the Scottish 'entrepreneurial ecosystem' diverges from the manner in which the ITI was designed to operate in a number of important respects (Table 1). First, there was a lack of indigenous entrepreneurs who wanted to take part in the ITI R\&D programmes. The original intention was that the R\&D programmes would mostly be undertaken by university researchers who would spin-out their research into new corporate 
ventures. This did not occur because, as noted earlier, most of the R\&D programmes were undertaken by private sector research contractors to produce IP that would then be licensed to new start-ups, thereby breaking the link between the inventors and the adopters of the research.

From a demand perspective, very few potential entrepreneurs actively sought involvement with the ITI with a view to starting a NTBF. This is perhaps unsurprising, given the region's historical lack of new business start-ups, which has been an enduring part of the Scottish economic landscape over the post war period despite considerable policy efforts directed towards raising the business birth rate (VAN STEL and STOREY, 2004; BROWN and MASON, 2012b). Another hallmark of Scotland's entrepreneurial ecosystem is the strong role of existing corporations as the main entrepreneurial incubator of new firms. A large number of 'new' firms emerge from existing corporate entities - as independent spin-outs, portfolio entrepreneurs (ROSA, 1999)) or through ownership changes such as management-buy-outs (MBOs). Recent research has shown that the most important source of NTBFs in Scotland is the existing stock of high-tech firms (BROWN and MASON, 2014). This situation is not unique to the Scottish economy (OAKEY, 2012). Despite this, a strong feature of much of Scotland's innovation policies, such as the ITI, is a strong focus on commercialising research undertaken from Scottish universities (LYALL, 2005).

The focus of the ITIs on generating IP within universities therefore seems counter to entrepreneurial patterns within Scotland's entrepreneurial ecosystem where businesses, rather than universities, are the main incubators of NTBFs. One R\&D provider interviewed suggested 
that a better model would have been for the ITI to jointly undertake the R\&D programmes with existing SMEs, either to embed the IP within those firms or through the creation of new entrepreneurial spin outs.

A further constraint on high-tech entrepreneurship in Scotland, in common with many other peripheral regions, is the deficiency of large scale 'patient' capital to aid the process of successful research commercialisation (MASON and PIERAKKIS, 2013). While public sector organisations like Scottish Enterprise have created local venture funds and stimulated a number of small business angel syndicates within Scotland (MASON et al, 2013), none of these are capable of assisting firms with major levels of funding (between $£ 2-20$ million) to help commercialise major disruptive technologies. Moreover, the investment approach of both venture capital funds and angel groups is to seek an exit, which results in a 'sell-off' mentality within Scotland's technology sector. Hence, for most entrepreneurs of technology-based firms, it is not a case of 'if' but 'when' to sell their company (OAKEY, 2003). Indeed, one firm involved in one of the ITI R\&D programmes was acquired shortly after the termination of the programme. The firm received close to $£ 1.5 \mathrm{~m}$ in funding from the programme. While the firm found the funding 'very useful' in helping with their expansion, the ultimate benefit of this R\&D funding went to the US multinational who acquired the firm. To our knowledge, at least one other firm funded through the ITI R\&D programmes has also been acquired. In summary, the ITI approach was incompatible with a small local financial system biased towards shorttermism, and lacking deep pockets (MAZZUCATO, 2013). 
Another barrier to the commercialisation of the research programmes concerns the nature of the existing business base in Scotland. The Scottish RIS is strongly characterised by a SME population with very low levels of business expenditure on research and development (BERD) (ROPER et al, 2006) and very weak levels of 'absorptive capacity' (HARRIS et al, 2013). The vast majority of Scottish SMEs do not conduct formal R\&D and very few license technologies from third parties such as universities or research providers (BROWN and MASON, 2014). Hence, for the vast majority of Scottish SMEs, the research being undertaken was well beyond the reach of their technological capabilities. It was noted by one interviewee that:

'SMEs many times do not have a strategic approach for technology transfer. They often do not know what they want and there is a lack of long-terms vision, awareness and resources'

Rather than formal R\&D processes, the nature of the innovation processes deployed by local innovative SMEs is often through 'open' interactions with customers, end-users and suppliers (LUTHJE et al, 2005; VON HIPPEL, 2009). These kinds of interactive open innovation processes are quite different to those used by larger enterprises with formal R\&D procedures; by adopting these inbound innovation processes, SMEs can compensate for a lack of internal resources (PARIDA et al, 2012). Indeed, the use of these open sources of innovation is often associated with superior economic performance by these smaller firms (BERCHICCI, 2013; BROWN and MASON, 2014). This was completely overlooked by the ITI programme, which meant that the 
intended 'customer base' for the technology being produced was largely unfamiliar and unreceptive to the process of licensing IP from third party organisations.

Another factor preventing local firms licensing IP is the dearth of technology-based firms in Scotland. Recent research shows that NTBFs constitute a very small overall proportion of the business base in Scotland (BROWN et al, 2012). Indeed, Scotland ranks the second lowest of all UK regions in terms of the proportion of its business base which are technology-based firms (BROWN et al, 2012). As a consequence, very few Scottish firms became research contractors for the R\&D programmes. One respondent noted that the dearth of Scottish technology companies with the capabilities to license IP meant that:

'there is no guarantee that the backward flow of economic benefits [to Scotland] is going to happen since it is possible that the Scottish companies wouldn't be able to deliver the expected development'

The ITI R\&D research programmes were exclusively focused on technological foresighting undertaken in three main high-technology areas outlined earlier. These areas were selected on the basis of the global market opportunities that were forecast rather than activities where Scotland had pre-existing strengths. With the exception of the energy sector, which has a substantial presence in Scotland and contributes around one-third of Scotland's technologybased firms (MASON and BROWN, 2012), the life sciences and the digital media sectors are 
both are small in size and have few research-oriented SMEs. Moreover, although the energy sector had potential to absorb some of the IP being developed, many of the research programmes undertaken by the energy division of the ITI focused on the renewable sector; a market that is still very embryonic in Scotland and dependent on subsidies. Here again, this shows a lack of recognition of the specificities of the local entrepreneurial ecosystem, which was largely incapable of connecting to and 'absorbing' the outputs from the ITI.

\section{CONCLUSION}

This paper has made a novel contribution to the innovation policy literature by examining the failure of, arguably, the UK's most ambitious ever 'systemic' policy instrument. It has been shown that ITI programme badly malfunctioned was not the policy panacea envisaged by policy makers. Based on the outdated linear model of innovation, it produced little of its anticipated commercial benefits. The design of the programme insufficiently connected the two sides of the RIS, leaving the knowledge production side and the knowledge exploitation elements isolated from one another. While reasonably effective at producing knowledge, the programme failed to properly harness the commercial benefits from the research, especially in terms of the numbers of NTBFs created.

The key problem with the ITI programme was its inability to properly diagnose the underlying structural problems within the RIS which are heavily shaped by the nature of the local entrepreneurial ecosystem. This confirms the view that more attention needs to be paid to the entrepreneurial propensity of innovation systems (RADOSEVIC and YORUK 2013). The findings have strong resonance for other peripheral regions with equally fragile entrepreneurial 
ecosystems (TOEDTLING and TRIPPL, 2005; MELANCON and DOLOREUX, 2013). They also suggest that the importance of entrepreneurial 'agency' within innovation systems needs to be better reflected within the systemic innovation literature (ACS et al, 2014). Given the nature of the Scottish entrepreneurial ecosystem, possibly a better 'policy mix' in this context would have been attempting to improve the overall levels of 'systemic capabilities' within the RIS (IAMMARINO et al, 2012) whilst fostering greater levels of open innovation within SMEs (BROWN and MASON, 2014).

This kind of 'bottom up' demand-led approach towards innovation is in stark contrast to the dominant supply-side logic hard-wired within innovation policy making in the UK. Indeed, the empirical findings strongly echo recent claims by the House of Commons Science and Technology Committee that UK innovation policy 'retains an implicit discredited linear model in many places' (HOUSE OF COMMONS, 2013, p. 9). Hence, despite the opportunities presented to policy makers from the process of political decentralisation within the UK (COOKE, 2005), the Scottish Government has been unable to break away from the dominant, linear logic of UK technology and innovation policy as a whole. This demonstrates that, despite the adoption of a RIS approach in Scotland, strong path dependencies continue to shape and mediate regional innovation 'policy spaces' (UYARRA E. and FLANAGAN, 2010) within the UK's multi-scaler innovation system.

It is important to stress the ITI's lack of success is not a reason for policy makers to curb their ambitions. Rather, the key issue is that policy failures need to be acknowledged and assessed so that policy-makers can learn and adapt in light of these experiences. Powerful insights can 
be gained from looking inside the policy 'black box'. To understand the full complexities of the policy making process however, innovation scholars need to scrutinize failure as well as successes. 


\section{ACKNOWLEDGEMENTS}

The authors are very grateful to the substantial numbers of people who were interviewed during this study. In addition to stakeholders and participating companies, numerous people in Scottish Enterprise and the ITI kindly provided input into the research. The authors would also like to thank Phil Cooke, Alex Coad, Suzanne Mawson and Fiona Wishlade for their constructive suggestions on earlier versions of the paper. They also wish to thank the very helpful comments from the referees. The usual disclaimer applies. 


\section{NOTES}

1. While this figure does seem very low, when we compare the situation in Scotland to elsewhere, the ITI's performance may be less disheartening. The German technology organisation Fraunhofer, which is often regarded as a best practice example for public financing of applied research commercialisation, provided support for 33 spin-off projects and produced 10 spin-offs in 2012 (FRAUNHOFER-GESSELSCHAFT, 2013). The Fraunhofer is a much larger research organisation with 67 research institutes, 23,000 employees and an annual R\&D budget

of almost $£ 2 \mathrm{bn}$. While the focus of this organisation is directed towards technology-transfer more generally, these relatively modest spin-off figures paint a more positive picture of the ITI's performance. The authors are very grateful to one of the anonymous referees for making the point about comparisons with other programmes. 


\section{REFERENCES}

ACS Z. and VARGA A. (2005) Entrepreneurship, Agglomeration and Technological Change, Small Business Economics, 24, 323-334.

ACS Z., AUTIO E., and SZERB, L. (2014) National Systems of Entrepreneurship: Measurement issues and policy implications, Research Policy, 43, 476-494.

ARNOLD E. (2004) Evaluating research and innovation policy: a systems world needs systems evaluations, Research Evaluation, 13, 3-17.

ASHEIM B. and COENEN L. (2005) Knowledge bases and regional innovation systems: Comparing Nordic Clusters, Research Policy, 34, 1173-1190.

ASHEIM B., LAWTON-SMITH, H. And OUGHTON C. (2011) Regional Innovation Systems: Theory, Empirics and Policy, Regional Studies, 45, 875-891.

AUDRETSCH, D. and FELDMAN, M. (1996) R\&D Spillovers and the Geography of Innovation and Production, The American Economic Review, 86, 630-640.

AUTIO E. (1998) Evaluation of RTD in regional systems of innovation, European Planning Studies, 6, 131-140.

BERCHICCI L. (2013) Towards and open R\&D system: Internal R\&D investment, external knowledge acquisition and innovative performance, Research Policy, 42, 117-127. 
BERCOVITZ J. and FELDMAN M. (2006) Entrepreneurial Universities and Technology Transfer: A Conceptual Framework for Understanding Knowledge-Based Economic Development, Journal of Technology Transfer, 31, 175-188.

BERGEK, A., JACOBSSON, S., LINDMARK, S. and RICKNE A, (2008)Analyzing the functional dynamics of technological innovation systems: A scheme of analysis, Research Policy, 37, 407429.

BEST M. (1990) The New Competition: Institutions of Industrial Restructuring, Polity Press, Cambridge.

BORRAS S. and EDQUIST, C. (2013) The choice of innovation policy instruments, Technological Forecasting and Social Change, 80, 1513-1522.

BOZEMAN B. (2000) Technology transfer and public policy: a review of research and theory, Research Policy, 29, 627-655.

BROWN R. and MASON C. (2012a) Raising the batting average: Re-orientating regional industrial policy to generate more high growth firms, Local Economy, 27, 33-49.

BROWN R. and Mason C. (2012b) The Evolution of Enterprise Policy in Scotland, In: Blackburn, R., Schaper, M., Government, SMEs and Entrepreneurship Development: Policy, Practice and Challenges,pp. 17-30, Gower Publishing, Aldershot.

BROWN, R and MASON, C. (2014) Inside the high-tech black box: A critique of technology entrepreneurship policy, Technovation, 34, 773-784. 
BROWN R., ANYADIKE-DANES M., HART., M., MASON C. and RICHMOND, K. (2012)The growth dynamics of technology-based firms in Scotland, Fraser of Allander Economic Commentary, 36, 56-65.

BROWN, R., MASON, C., and MAWSON, S. (2014) Increasing 'the Vital 6\%': Designing Effective Public Policy to Support High Growth Firms, Working Paper 14/01, NESTA, London.

http://www.nesta.org.uk/sites/default/files/working_paper_-

_increasing_the_vital_6_percent.pdf

CARLSSON B., JACOBSSON S., HOLEMEN M. and RICKNE A. (2002) Innovation Systems: Analytical and Methodological Issues, Research Policy,31,233-245.

CARLSSON, B. (2006) Internationalization of innovation systems: A survey of the literature, Research Policy, 35, 56-67.

CHESBROUGH, H. W., (2003) Open Innovation: The New Imperative for Creating and Profiting from Technology, Harvard Business School Publishing, Boston.

CHESBROUGH H. and CROWTHER A. (2006) Beyond high tech: early adopters of open innovation in other industries, R\&D Management, 36, 229-236.

COHEN W. and LEVEINTHAL D. (1990) Absorptive Capacity: a new perspective on learning and innovation, Administrative Science Quarterly, 35, 128-152.

COOKE P., URANGA, M. and ETXEBARRIA G. (1997) Regional Innovation systems: Institutional and Organisational dimensions, Research Policy, 26, 475-491. 
COOKE P., BOEKHOLT P., and TOEDTLING F. (2000) The Governance of Innovation in Europe, Pinter, London.

COOKE P. (2004) Integrating global knowledge flows for generative growth in Scotland: life sciences as a knowledge economy exemplar, in Global Knowledge Flows and Economic Development, pp.73-96, OECD, Paris.

COOKE, P. (2005) Devolution and Innovation: the Financing of Economic Development in the UK's Devolved Administrations, Scottish Affairs, 50, 39-50.

COOKE, P. and LEYDESDORFF, L., (2006) Regional Development in the Knowledge-Based Economy: The Construction of Advantage, The Journal of Technology Transfer, 31, 5-31.

COX D. and RIGBY D. (2013) Innovation Policy Challenges for the $21^{\text {st }}$ Century, Routledge, London.

CRESPI F. and QUATRARO F. (2013) Systemic technology policies: issues and instruments, Technological Forecasting and Social Change, 80, 1447-1449.

DIEZ, M. (2001) The Evaluation of Regional Innovation and Cluster Policies: Towards a Participatory Approach, European Planning Studies, 9, 907-923.

DODGSON, M., HUGHES, A., FOSTER, J. and METCALFE, S., 2011. Systems thinking, market failure, and the development of innovation policy: The case of Australia, Research Policy, 40, 1145-1156. 
EASTERBY-SMITH M., THORPE R. and LOWE A. (2002) Management Research: An Introduction, Sage, London.

EDGAR J. (2009) Intermediary technology institutes: their role in promoting innovation and economic development in Scotland. Paper presented at the $7^{\text {th }}$ Triple Helix International Conference, Glasgow, UK, 17-19 June 2009

EDQUIST C. (2004) Systems of innovation: perspectives and challenges, in Fagerberg J., Mowery, D. and Nelson R. (Eds.), The Oxford Handbook of Innovation. Oxford University Press, Oxford.

EDQUIST C. (2011) Design of innovation policy through diagnostic analysis: identification of systemic problems (or failures), Industrial and Corporate Change, 20, 1725-1753.

ETZKOWITZ H. (2006) The new visible hand: An assisted linear model of science and innovation policy, Science and Public Policy, 33, 310-320.

FELDMAN M. and KELLEY M. (2006) The exante assessment of knowledge spillovers: Government R\&D policy, economic incentives and private firm behavior, Research Policy, 35, $1509-1521$.

FISCHER E. and REUBER A. (2003) Support for Rapid-Growth Firms: A Comparison of the Views of Founders, Government Policymakers, and Private Sector Resource Providers, Journal of Small Business Management, 41, 346-365.

FLANAGAN K. UYARRA E. and LARANJA, M. (2011) Reconceptualising the 'policy mix' for innovation, Research Policy, 40, 702-713. 
FRAUNHOFER-GESELLSCHAFT (2013) Annual Report 2012: Research for Greater Efficiency, Fraunhofer-Gesellschaft, Munchen.http://www.fraunhofer.de/content/dam/zv/en/Publications/AnnualReport/Fraunhofer-Annual-Report_2012.pdf

FREEMAN, C. (1995) The 'National System of Innovation' in historical perspective, Cambridge Journal of Economics, 19, 5-24.

GERTLER, M. (2010) Rules of the Game: The Place of Institutions in Regional Economic Change, Regional Studies, 44, 1-15.

GRAEBNER M., MARTIN J. and ROUNDY P. (2012) Qualitative data: cooking without a recipe, Strategic Organization, 10, 276-284.

GREENE F. and STOREY D. (2007) Issues in Evaluation: The Case of Shell Livewire, in Audretsch D., GRILO I. and THURIK R. (Eds)Handbook of Research on Entrepreneurship Policy, Edward Elgar, Cheltenham.

HARRIS R., LI, Q. And MOFFAT J. (2013) The Impact of Higher Education Institution-Firm Knowledge Links on Establishment-Level Productivity in British Regions, The Manchester School, 81, 143-162.

HARRISON, R. and LEITCH, C. (2010) Voodoo Institution or Entrepreneurial University? Spin-Off Companies, the Entrepreneurial System and Regional Development in the UK, Regional Studies, 44, 1241-1262. 
HEWITT-DUNDAS N. and ROPER S. (2011) Creating advantage in peripheral regions: the role of publicly-funded R\&D centres, Research Policy, 40, 832-841.

HOWELLS J. (1999) Regional systems of innovation? in ARCHIBUGI, D., HOWELLS J. andMICHIE, J. (Eds) Innovation Policy in a Global Economy, Cambridge University Press, Cambridge.

HOUSE OF COMMONS(2013) Bridging the valley of death: Improving the commercialisation of research, Science and Technology Committee, House of Commons, London. Download from: http://www.publications.parliament.uk/pa/cm201213/cmselect/cmsctech/348/348.pdf

HUGGINS R. and KITAGAWA F. (2012) Regional Policy and University Knowledge Transfer: Perspectives from Devolved Regions in the UK, Regional Studies, 46, 817-832.

IAMMARINO S., PIVA M., VIVARELLI M. and VON TUNZELMANN, N (2012) Technological Capabilities and Patterns of Innovative Cooperation of Firms in the UK Regions, Regional Studies, 46, 1283-1301.

INTELLECTUAL PROPERTY OFFICE (2012) Facts and Figures 2010 and 2011 Calendar Years. Intellectual Property Office, Newport. Download from: http://www.ipo.gov.uk/aboutfacts1011.pdf

ITI SCOTLAND (2008) ORIGINS OF PROGRAMMES (Life Science, Techmedia and Energy), ITI Scotland, Glasgow.

KEATING M. (2005) Policy convergence and divergence in Scotland under devolution, Regional Studies, 39, 453-463. 
LUNDVALL B. (1992) Introduction, in Lundvall B. (Ed) National Systems of Innovation - Toward a Theory of Innovation and Interactive Learning, pp.1-19, Pinter Publishers, London.

LUNDVALL B. A., 2007. National Innovation Systems - Analytical Concept and Development Tool, Industry and Innovation, 14, 95-119.

LUTHJE C., HERSTATT C. and VON HIPPEL (2005) User-innovations and 'local' information: the case of mountain biking, Research Policy, 34, 951-965.

LYALL, C. (2005) Scotland's science strategy: an exercise in concurrent power? Scottish Affairs, $52,51-70$.

LYALL C. (2007) Changing boundaries: the role of policy networks in the multi-level governance of science and innovation in Scotland, Science and Public Policy, 34, 3-14.

MALERBA, F. (2002) Sectoral systems of innovation and production, Research Policy, 31, 247264.

MANN R. and SAGER T. (2007) Patents, venture capital and software startups, Research Policy, 36, 193-208.

MARKUSEN, A. (2000) Can Technology Policy Serve as Industrial Policy? In HOWES, C. and SINGH, A. (Eds) Competitiveness Matters: Industry and Economic Performance in the US, pp. 127-144.University of Michagan Press, Ann Arbor.

MASON, C. and BROWN, R. (2010) High Growth Firms in Scotland, Scottish Enterprise, Glasgow. [http://www.scottish-enterprise.com/start-your- 
business/ /media/publications/About\%20Us/economic

\%20research/HighGrowthFirmsReportNovember2010.ashx]

MASON, C. and BROWN, R. C. (2012) Technology-based firms in Scotland, Scottish Enterprise, Glasgow.[http://www.scottish-

enterprise.com/ /media/SE/Resources/Documents/STUV/Technology-Based-Firms-inScotland.pdf]

MASON C. and PIERRAKIS, Y. (2013) Venture Capital, the Regions, and Public Policy: The United Kingdom since the post-2000 Technology Crash, Regional Studies, 47, 1156-1171.

MASON C. and BROWN R. (2013) Creating good public policy to support high growth firms, Small Business Economics, 40, 211-225.

MASON, C. and BROWN, R. (2014) Entrepreneurial Ecosystems and Growth-Oriented Entrepreneurship, Background Paper for the LEED Programme, OECD, Paris. http://www.oecd.org/cfe/leed/Entrepreneurial-ecosystems.pdf

MAZZUCATO M. (2013) The Entrepreneurial State: Debunking Public vs. Private Sector Myths, Anthem Press, London.

MELANCON Y. And DOLOREUX D. (2013) Developing a Knowledge Infrastructure to Foster Regional Innovation in the Periphery: A Study from Quebec's Coastal Region in Canada, Regional Studies, 47, 1555-1572. 
METCALFE S. 1997. Technology systems and technology policy in an evolutionary framework in ARCHIBUGI D. and MICHIE J. (Eds) Technology, Globalisation and Economic Performance, pp. 268-296, Cambridge University Press, Cambridge.

MOLINA A. and GREGSON G. (2002) Real-time Evaluation Methodology as a Learning Instrument in High Technology SME Support Networks, International Journal of Entrepreneurship and Innovation Management, 2, 69-99.

MORGAN K. (1997) The Learning Region: Institutions, Innovation and Regional Renewal, Regional Studies, 31, 491-503.

NELSON R. and WINTER S. (1982) An Evolutionary Theory of Economic Change, Harvard University Press, Boston, MA.

OAKEY R. (2003) Technical entrepreneurship in high technology small firms: some observations on the implications for management. Technovation,23, 679-688.

OAKEY R. (2012) Open innovation and its relevance to industrial research and development: The case of high-technology small firms, International Small Business Journal, 31, 319-336.

OECD (2004) Global Knowledge Flows and Economic Development, LEED Programme, OECD, Paris.

OECD (2010) The OECD Innovation Strategy: Getting A Head Start on Tomorrow, OECD, Paris.

OUGHTON C. LANDABASO M. and MORGAN K. (2002) The Regional Innovation Paradox: Innovation Policy and Industrial Policy, The Journal of Technology Transfer, 27, 97-110. 
PARIDA J., WESTERBERG, M. and FRISHAMMER, J. (2012) Inbound Open Innovation Activities in High-Tech SMEs: The Impact on Innovation Performance, Journal of Small Business Management, 50, 283-309.

RADOSEVIC S. and YORUK E. (2013) Entrepreneurial propensity of innovation systems: Theory, methodology and evidence, Research Policy, 42, 1015-1038.

ROPER S., LOVE J. and COOKE P. (2006) The Scottish Innovation System: Actors, Roles and Actions, Report for the Scottish Government, Edinburgh. Download from: http://www.scotland.gov.uk/Resource/Doc/89713/0021562.pdf

ROSA, P. (1999) The prevalence of multiple owners and directors in the SME sector: implications for our understanding of start-up and growth, Entrepreneurship and Regional Development, 11, 21-37.

SALTER A. and MARTIN B. (2001) The economic benefits of publicly funded basic research: a critical review, Research Policy, 30, 509-532.

SCOTTISH EXECUTIVE (2004) A Smart, Successful Scotland, Scottish Executive, Edinburgh.http://www.scotland.gov.uk/Resource/Doc/26800/0027981.pdf

SCOTTISH GOVERNMENT (2013) Business Enterprise Research and Development Scotland, Scottish Government, Glasgow. http://www.scotland.gov.uk/Resource/0044/00447162.pdf

SHARIF N. (2006) Emergence and development of the National Innovation Systems Concept, Research Policy, 35, 745-766. 
SMITS R. and KUHLMANN S. 2004.The rise of systemic instruments in innovation policy, International Journal of Foresight and Innovation Policy, 1, 4-32.

TARGETING TECHNOLOGY (2008) Scottish University Spin-Off Study, Targeting Innovation, Glasgow.

THE HERALD (2010) SE writes off $£ 32 m$ investment as it 'abandons' technology scheme, 21,11.10.

THE HERALD (2013) Ten years and $£ 231 \mathrm{~m}$ invested in the ITIs - but just 600,000 royalities to show for it, $17,3.13$

TOEDTLING F. and TRIPPL M. (2005) One Size Fits All? Towards a Differentiated Regional Innovation Policy Approach, Research Policy, 34, 1203-1219.

TUROK I. (1991) Policy evaluation as science: a critical assessment, Applied Economics, 23, 1543-1550.

UYARRA E. (2010) What is evolutionary about 'regional systems of innovation'? Implications for regional policy, Journal of Evolutionary Economics, 20, 681-695.

UYARRA E. and FLANAGAN, K. (2010) From regional systems of innovation to regions as innovation policy spaces, Environment and Planning C: Government and Policy, 28, 681-695

VON HIPPEL E. (2009) Democratizing Innovation: The Evolving Phenomenon of User Innovation, International Journal of Innovation Science,1, 29-40. 
VAN STEL A. and STOREY D. (2004) The Link Between Firm Births and Job Creation: Is there a Upas Tree Effect?, Regional Studies,38, 893-909.

WARWICK K. (2013) Beyond Industrial Policy: Emerging Issues and New Trends, OECD Science, Technology and Industry Policy Papers, No. 2, OECD Publishing, Paris.

WIECZOREK A. and HEKKERT M. (2012) Systemic instruments for systemic innovation problems: A framework for policy makers and innovation scholars, Science and Public Policy, 39, 74-87.

YOUNG B., HEWITT-DUNDAS, N. and ROPER S. (2008) Intellectual Property Management in Publically Funded R\&D Centres: A Comparison of University-based and Company-based Research Centres, Technovation, 28, 473-484. 